Nevada

Environmental

Restoration

Project

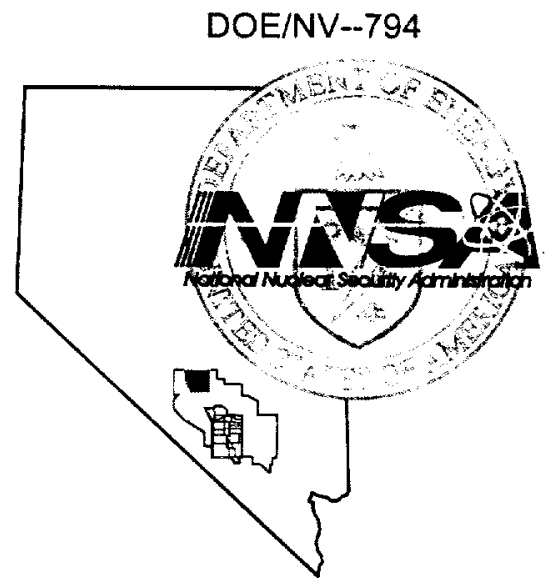

Post-Closure Inspection Report for Corrective Action Unit 404: Roller Coaster Lagoons and Trench Tonopah Test Range, Nevada Calendar Year 2001

Controlled Copy No.:

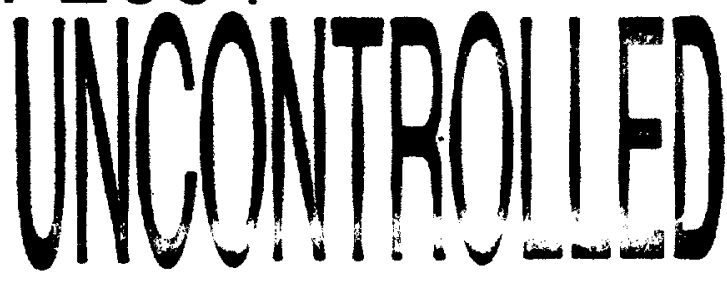

Revision: 0

January 2002

Environmental Restoration

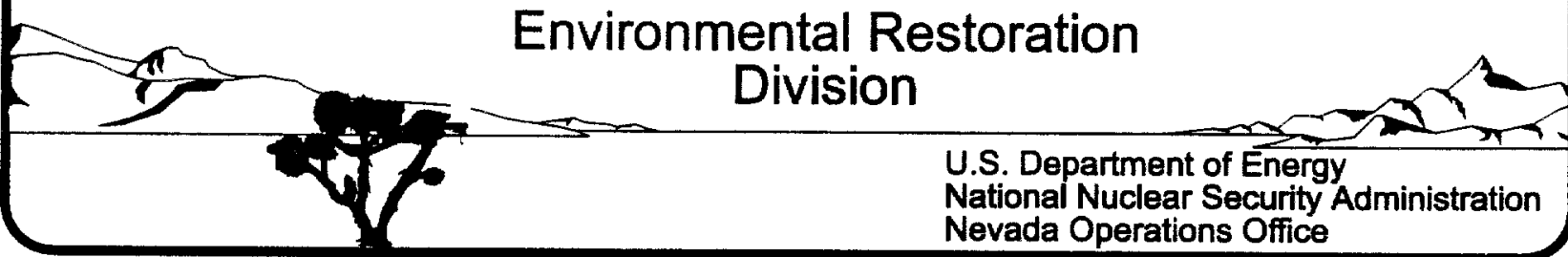




\section{DISCLAIMER STATEMENT}

Reference herein to any specific commercial product, process, or service by trade name, trademark, manufacturer, or otherwise, does not necessarily constitute or imply its endorsement, recommendation, or favoring by the U.S. Government or any agency thereof or its contractors or subcontractors.

\section{AVAILABILITY STATEMENT}

Available for sale to the public from-

U.S. Department of Commerce

National Technical Information Service

5285 Port Royal Road

Springfield, VA 22161-0002

Telephone: 800.553 .6847

Fax: 703.605.6900

E-mail: orders@ntis.fedworld.gov

Online ordering: http://www.ntis.gov/ordering.htm

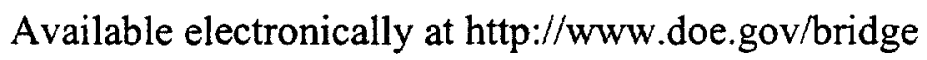

Available for a processing fee to U.S. Department of Energy and its contractors, in paper, from-

U.S. Department of Energy

Office of Scientific and Technical Information

P.O. Box 62

Oak Ridge, TN 37831-0062

Telephone: 865.576.8401

Fax: 865.576.5728

E-mail: reports@adonis.osti.gov 


\title{
POST-CLOSURE INSPECTION REPORT FOR CORRECTIVE ACTION UNIT 404: ROLLER COASTER LAGOONS AND TRENCH TONOPAH TEST RANGE, NEVADA CALENDAR YEAR 2001
}

\author{
Prepared for \\ U. S. Department of Energy \\ National Nuclear Security Administration \\ Nevada Operations Office \\ Work Performed Under Contract No. \\ DE-AC08-96NV11718
}

Controlled Copy No.:

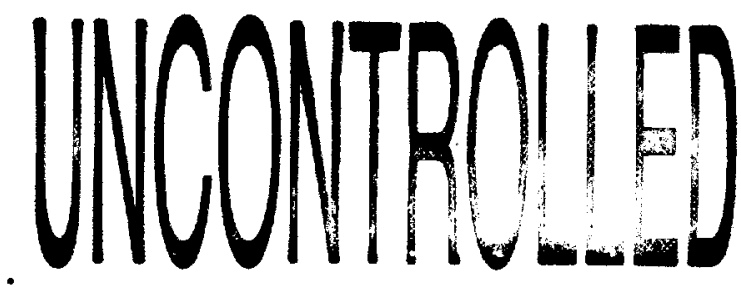

Revision: 0

January 2002 


\section{POST-CLOSURE INSPECTION REPORT FOR CORRECTIVE ACTION UNIT 404: ROLLER COASTER LAGOONS AND TRENCH TONOPAH TEST RANGE, NEVADA CALENDAR YEAR 2001}

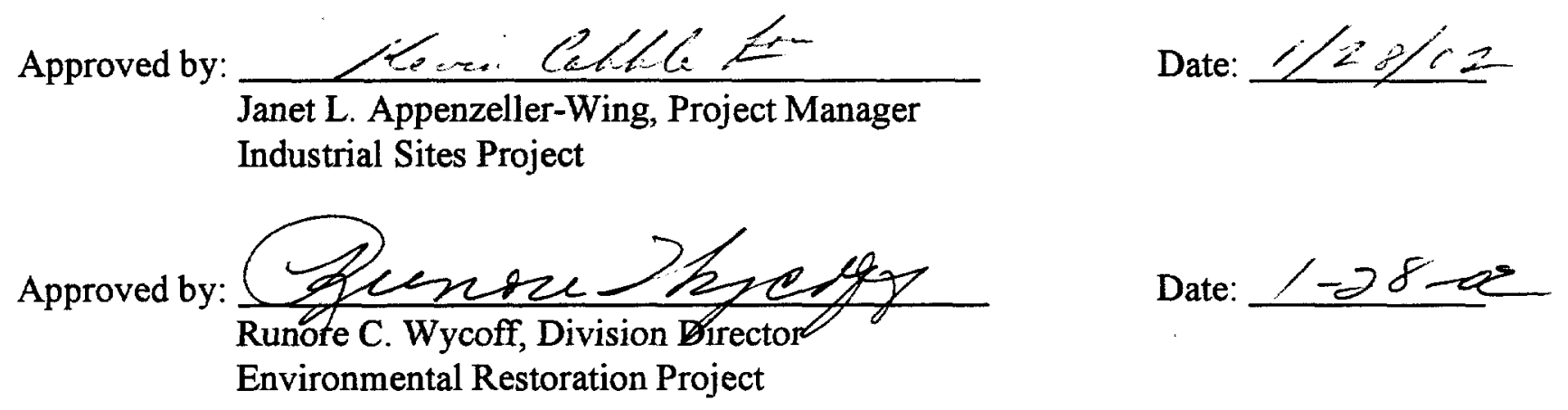




\section{TABLE OF CONTENTS}

LIST OF ACRONYMS AND ABBREVIATIONS $\ldots \ldots \ldots \ldots \ldots \ldots \ldots \ldots \ldots$ vii

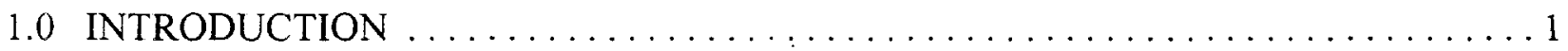

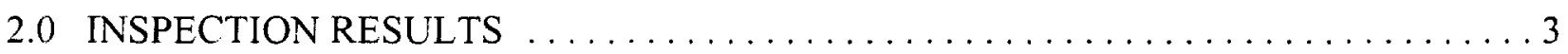

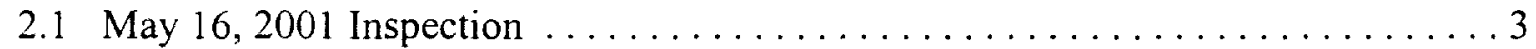

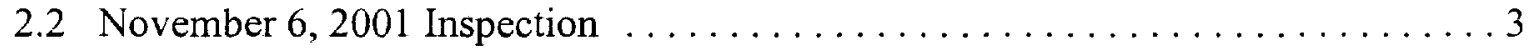

3.0 CONCLUSIONS AND RECOMMENDATIONS $\ldots \ldots \ldots \ldots \ldots \ldots \ldots \ldots \ldots \ldots$

\section{FIGURES}

FIGURE 1 - ROLLER COASTER LAGOONS AND TRENCH CAU 404 LOCATION

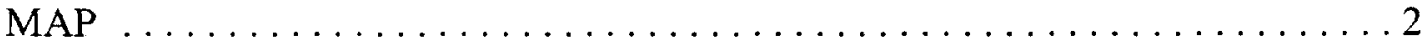

\section{ATTACHMENTS}

ATTACHMENT A - INSPECTION CHECKLISTS

ATTACHMENT B - FIELD NOTES

ATTACHMENT C - PHOTOGRAPH LOG AND PHOTOGRAPHS

DISTRIBUTION LIST 
Post-Closure Inspection Report CAUNo. 404

Roller Coaster I.agoons \& Trench

Revision: 0

Date: January 23, 2002

THIS PAGE INTENTIONALLY LEFT BLANK 


\section{LIST OF ACRONYMS AND ABBREVIATIONS}

$\begin{array}{ll}\text { CAU } & \text { Corrective Action Unit } \\ \mathrm{cm} & \text { centimeter } \\ \mathrm{CR} & \text { Closure Report } \\ \text { in } & \text { inch } \\ \text { NDEP } & \text { Nevada Division of Environmental Protections }\end{array}$


Post-Closure Inspection Report

CAU No. 404

Roller Coaster Lagoons \& Trench

Revision: $U$

Date: January 23. 2002

THIS PAGE INTENTIONALLY LEFT BLANK 


\subsection{INTRODUCTION}

Post-closure monitoring requirements for the Roller Coaster Lagoons and Trench (Corrective Action Unit [CAU] 404) (Figure 1) are described in Closure Report for Corrective Action Unit 404, Roller Coaster Sewage Lagoons and North Disposal Trench, Tonopah Test Range, Nevada, report number DOE/NV--187, September 1998. The Closure Report (CR) was submitted to the Nevada Division of Environmental Protection (NDEP) on September 11, 1998. Permeability results of soils adjacent to the engineered cover and a request for closure of CAU 404 were transmitted to the NDEP on April 29, 1999. The CR (containing the Post-Closure Monitoring Plan) was approved by the NDEP on May 18, 1999.

As stated in Section 5.0 of the NDEP-approved CR, post-closure monitoring at CAU 404 consists of the following:

- Visual site inspections done twice a year to evaluate the condition of the cover and plant development.

- Verification that the site is secure and condition of the fence and posted warning signs.

- Notice of any subsidence, erosion, unauthorized excavation, etc., deficiencies that may compromise the integrity of the unit.

- $\quad$ Remedy of any deficiencies within 90 days of discovery.

- Preparation and submittal of an annual report.

In addition to the above activities, vegetative monitoring of the cover (a plant census) will be done in the first, third and fifth year following revegetation. (Vegetative monitoring will done in fiscal year 2001, and the results reported in the 2002 Post-Closure Inspection Report.)

Site inspections were conducted on May 16, 2001, and November 6, 2001. The site inspections were conducted after completion of the revegetation activities (October 30, 1997) and NDEP approval of the CR (May 18, 1999). All site inspections were conducted in accordance with the Post-Closure Monitoring Plan in the NDEP-approved CR.

This report includes copies of inspection checklists, photographs, recommendations, and conclusions. The Post-Closure Inspection Checklists are found in Attachment A, a copy of the field notes is found in Attachment B, and copies of the inspection photographs are found in Attachment C. 

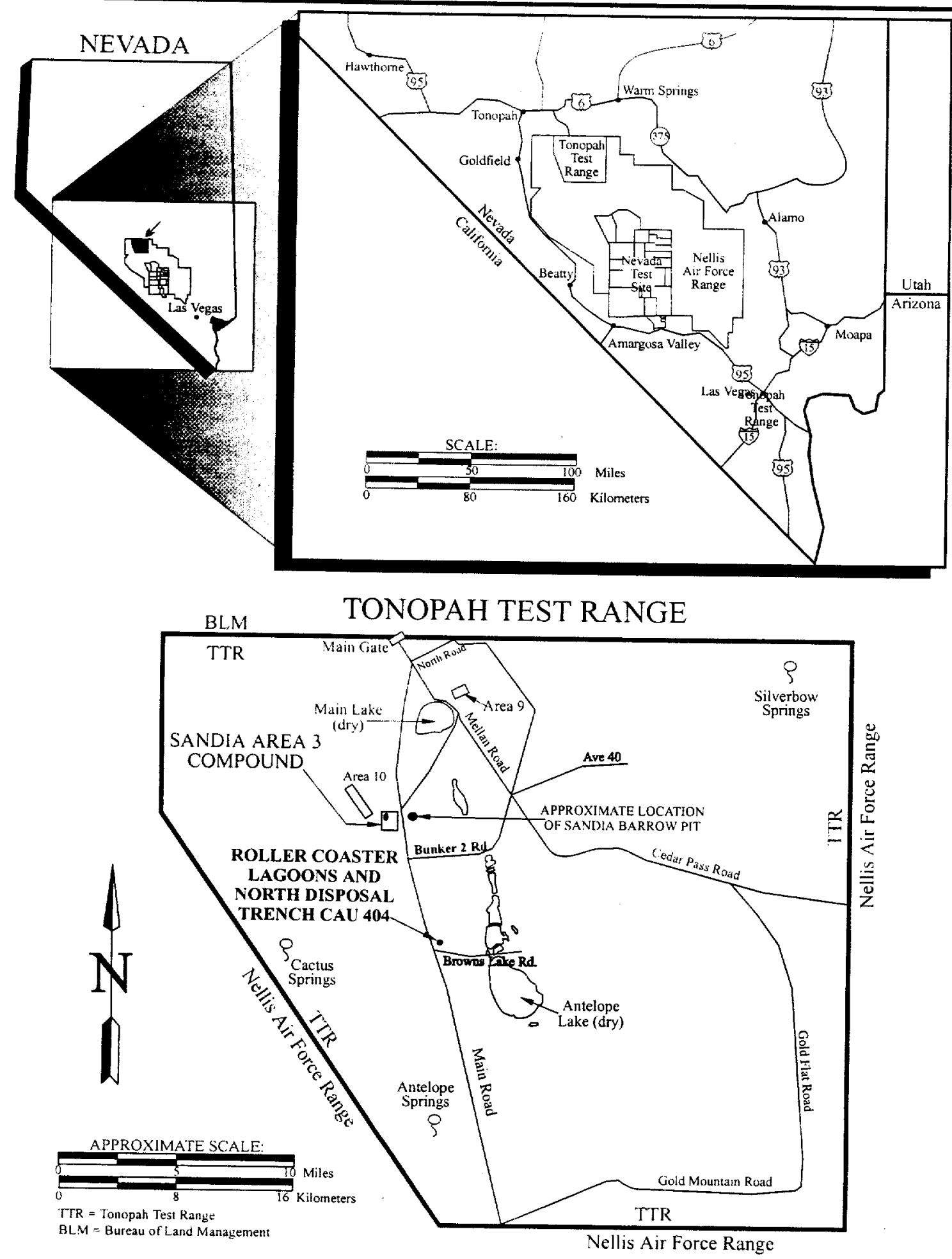

FIGURE 1

ROLLER COASTER LAGOONS AND TRENCH CAU 404 LOCATION MAP 
Post-Closure Inspection Report

CAUI No. 404

Roller Coaster Lagoons \& Trench

Revision: 0

Date: January 23, 2002

\subsection{INSPECTION RESULTS}

\subsection{May 16, 2001 Inspection}

The first inspection was completed on May 16, 2001. Numerous small mammal burrows were observed along cover side slopes inside the fenced area. The majority of observed burrows were located along the toe of the cover side slopes. The burrows measured approximately 5 centimeters $(\mathrm{cm})$ ( 2 inches [in]) in diameter. Small animal burrows and scratchings were also present along the fence line, both inside and outside the fence line. The burrows did not effect the integrity of the cover. The fence and the chicken wire mesh fence were in good repair with no apparent holes or breaches in the fencing. Two warning signs that were originally attached to the fence had fallen off at the time of inspection. The signs were propped up in place between the chicken wire and barbed wire. No erosion, subsidence, or cracking of the cover surface was observed. The vegetation inside the fence and on the cover appeared to be healthy and well established. Overall, the cover, fencing, and the area inside the fence were observed to be stable and in good condition. No further maintenance or repairs were recommended.

\subsection{November 6, 2001 Inspection}

The second inspection was completed on November 6,2001. Numerous small shallow burrow and scratchings approximately $5 \mathrm{~cm}$ (2 in) in width and depth were observed at the toe of the cover side slopes. Small mammal burrows were also present along the perimeter of the fence, both inside and outside the fence. Mammal burrows at the base of the fence were backfilled using a shovel. The wire fence, chicken wire mesh, and gates were all in excellent condition. Small erosion rills present on the cover side slopes were backfilled using a shovel. Two warning signs originally attached to the fence had become unattached. These signs were reattached to the fence using new steel hog rings. The vegetation on the cover and inside the fenced area was well established and healthy, with predominantly native grass and brush species present. There was no evidence of erosion, settling, or cracking to the cover. The integrity of the cover unit was excellent. No further maintenance or repairs were recommended.

\subsection{CONCLUSIONS AND RECOMMENDATIONS}

Minor grazing by rabbits has been observed; however, the plant population remains diverse. Numerous small mammal burrows are present along the toe of the cover but do not appear to effect the integrity of the cover. Small mammals have burrowed under the fence at several locations: these burrows were backfilled using a shovel. Minor erosion rills and features observed on the cover were backfilled by hand using a shovel. The minor erosion observed does not impact the cover integrity. The overland runoff is being properly diverted around the site. There is no evidence of drainage or erosion through the site. The condition of the cover is 
excellent, with a good diversity of plant species growing on the cover and within the fenced area. Overall, the cover area, fencing, posted warning signs, and gates were all in excellent condition. No further maintenance or repairs were recommended.

Vegetation monitoring was conducted during the 2000 site inspections and was reported in the Post-Closure Inspection Report for Corrective Action Unit 404: Roller Coaster Sewage Lagoons and North Disposal Trench. Tonopah Test Range, Nevada Calendar Year 2000 report number $\mathrm{DOE} / \mathrm{NV}-\mathbf{- 7 3 5}$, June 2001. Vegetation monitoring is recommended for the fifth year (2002) after revegetation as proposed in the CR. Results of the 2002 vegetation monitoring will be reported in the Post-Closure Inspection Report for Calendar Year 2002. No modifications or repairs to the cover, or changes in the frequency of site inspections, are recommended at this time. 
Post-Closure Inspection Report

CAL: No. 404

Roller Coaster l agoons \& Trench

Revision: 0

Date: January 23, 2002

\section{ATTACHMENT A}

\section{INSPECTION CHECKLISTS}


Roller Coaster Lagoons \& Trench

Revision: 0

Date: January 23,2002

$\%$ 
CAU 404: ROLLER COASTER LAGOONS \& N. DISPOSAL TRENCH, POST-CLOSURE MONITORING CHECKLIST

\begin{tabular}{|c|c|}
\hline Date of Last inspection: $21 \mathrm{Nov} 2000$ & 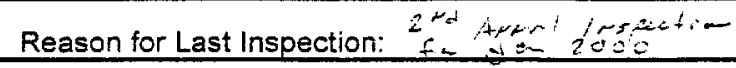 \\
\hline Responsible Agency: BN-En DOE-NV & Project Manager: Wrype Jobrso- \\
\hline Inspection Date: $\quad / 6 / A, 42001$ & \\
\hline Inspector (name, title, organization): Burd Javlis.o & Matose \\
\hline
\end{tabular}

A. GENERAL INSTRUCTIONS

1. All checklist items must be completed and detailed comments made to document the results of the site inspection. The completed checklist is part of the field record of the inspection. Additional pages should be used as necessary to ensure that a complete record is made. Attach the additional pages and number all pages upon completion of the inspection.

3. Any checklist line item marked by an inspector in a SHADED BOX, must be fully explained or an appropriate reference to previous reports provided. The purpose of this requirement is to provide a written explanation of inspector observations and the inspector's rationale for conclusions and recommendations. Explanations are to be placed on additional attachiments and cross-referenced appropriately. Explanations, in addition to narrative, will take the form of sketches measurements, annotated site maps.

4. The site inspection is a walking inspection of the entire site including the perimeter and sufficient transects to be able to inspect the entire surface and all features specifically described in this checklist.

5. A standard set of color $35 \mathrm{~mm}$ photographs is required. In addition, all anomalous features or new features (such as changes in adjacent area land use) are to be photographed. A photo log entry will be made for each photograph taken.

6. This unit will be inspected biannually with formal reporting to the Nevada Division of Environmental Protection to be done annually. The annual report will include an executive summary, this inspection checklist with field notes and photo log attached, and recommendations and conclusions.

B. PREPARATION (To be completed prior to site visit)

1. Site as-built plans and site base map reviewed.

2. Previous inspection reports reviewed.

a. Were anomalies or trends detected on previous inspections?

b. Was maintenance performed?

3. Site maintenance and repair records reviewed.

a. Has site repair resulted in a change from as-built conditions?

b. Are revised as-builts available that reflect repair changes?

C. SITE INSPECTION (To be completed during inspection)

\begin{tabular}{|c|c|c|c|}
\hline & YES & NO & EXPLANATION \\
\hline & $\mathcal{I}$ & & \\
\hline & 1 & & \\
\hline & & & \\
\hline & & $\checkmark$ & \\
\hline & & $\checkmark$ & Pa previos bepans \\
\hline & & $\checkmark$ & NA \\
\hline anges? & & $\checkmark$ & $\checkmark A$ \\
\hline & YES & NO & EXPLANATION \\
\hline
\end{tabular}

1. Adjacent off-site features within watershed areas.

a. Have there been any changes in use of adjacent area?

b. Are there any new roads or trails?

c. Has there been a change in the position of nearby washes?

d. Has there been lateral excursion or erosion/deposition of nearby washes?

e. Are there new drainage channels?

f. Change in surrounding vegetation?

\begin{tabular}{|l|l|l|}
\hline & $\nearrow$ & \\
\hline & $\checkmark$ & \\
\hline & $\nearrow$ & \\
\hline & $\nearrow$ & \\
& $\checkmark$ & \\
\hline & $\nearrow$ & \\
\hline & $\checkmark$ & \\
\hline
\end{tabular}

2. Security fence, signs.

a. Displacement of fences, site markers, boundary markers, or monuments?

b. Have any signs been damaged or removed?

(Number of signs replaced:

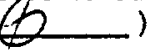

c. Were gates locked?

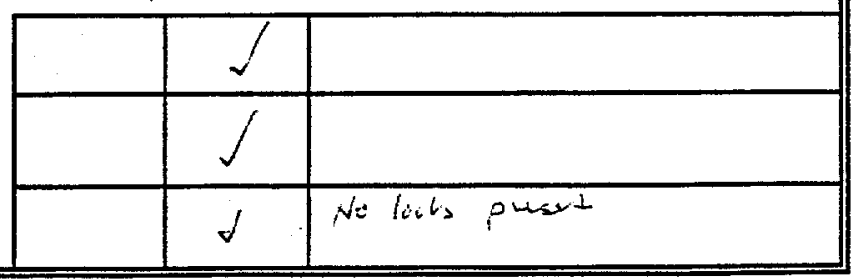




\section{CAU 404: ROLLER COASTER LAGOONS \& N. DISPOSAL TRENCH, POST-CLOSURE MONITORING}

CHECKLIST

3. Waste Unit cover.

a. Is there evidence of settling?

b. Is there cracking?

c. Is there evidence of erosion around the cap (wind or water)?

d. Is there evidence of animal burrowing?

e. Have the site markers been disturbed by man or natural processes?

f. Do natural processes threaten to integrity of any cover or site marker?

g. Other?

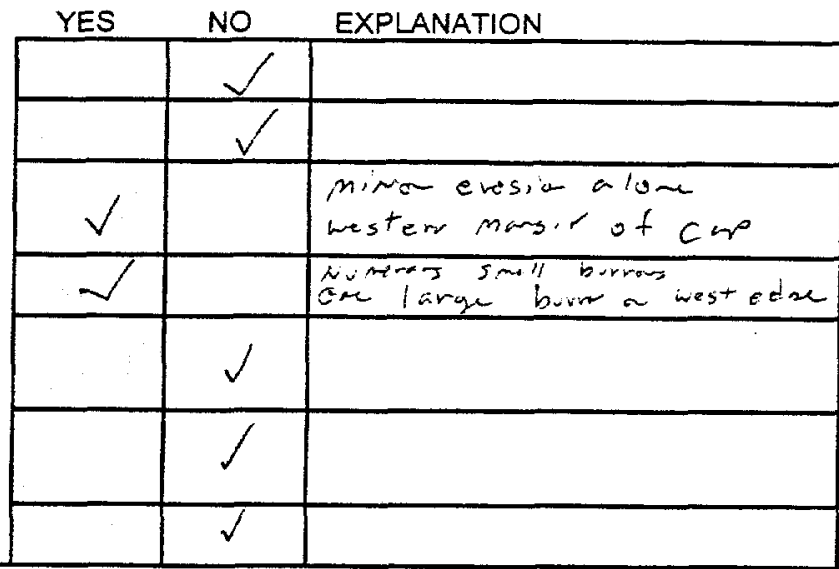

4. Vegetative cover.

a. Is perimeter fence or mesh fencing damaged?

b. Is there evidence of horses or rabbits on site?

c. Is organic mulch adequate to prevent erosion?

d. Are weedy annual plants present? If yes, are they a problem?

e. Are seeded plant species found on site?

f. Is there evidence of plant mortality?

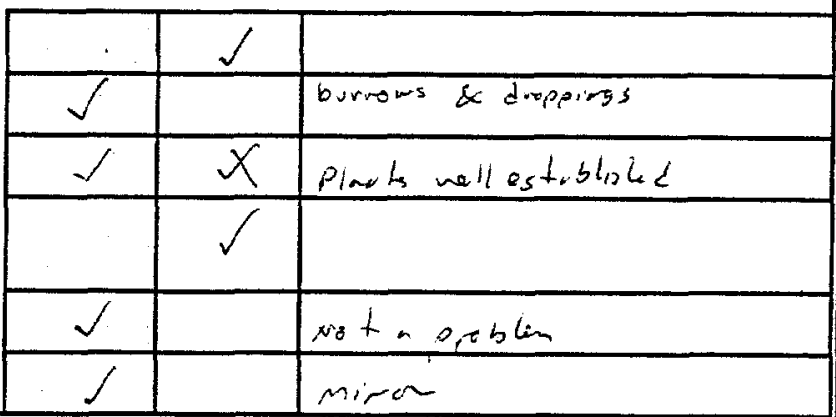

5. Photo Documentation

a. Has a photo log been prepared?

c. Number of photos exposed $(9$

\section{FIELD CONCLUSIONS}

1. Is there an imminent hazard to the integrity of the unit? (Immediate report required)

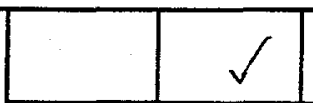

Person/Agency to whom report made

2. Are more frequent inspections required?

3. Are existing maintenance/repair actions satisfactory?

4. Is other maintenance/repair necessary?

5. Is current status/condition of vegetative cover satisfactory?

6. Rationale for field conclusions: Coven is good cordition.

\section{E. CERTIFICATION}

I have conducted an inspection of the Roller Coaster Sewage Lagoons \& North Disposal Trench, CAU 404, at the TTR in accordance with the Post-Closure Monitoring Plan (see Closure Report) as recorded on this checklist, attached sheets, field notes, photo logs, and photographs.

Chief inspector's signature: $\mathrm{Pr}$ Printed Name: Brid Dovlas 


\section{CAU 404: ROLLER COASTER LAGOONS \& N. DISPOSAL TRENCH, POST-CLOSURE MONITORING CHECKLIST}

\begin{tabular}{||l|l|}
\hline \hline Date of Last Inspection: $16 M a y 2001$ & Reason for Last inspection: \\
\hline Responsible Agency: NNSA /NU BNER & Project Manager: \\
\hline Inspection Date: 6 NOVember 2001 & \\
\hline Inspector (name, title, organization): Kewin B. Campbell, Technical Lead, BN ER \\
\hline Assistant Inspector (name, title, organization): NA
\end{tabular}

A. GENERAL INSTRUCTIONS

1. All checklist items must be completed and detailed comments made to document the results of the site inspection. The completed checklist is part of the field record of the inspection. Additional pages should be used as necessary to ensure that a complete record is made. Attach the additional pages and number all pages upon completion of the inspection.

2. Any checklist line item marked by an inspector in a SHADED BOX, must be fully explained or an appropriate reference to previous reports provided. The purpose of this requirement is to provide a written explanation of inspector observations and the inspector's rationale for conclusions and recommendations. Explanations are to be placed on additional attachments and cross-referenced appropriately. Explanations, in addition to narrative, will take the form of sketches, measurements, annotated site maps.

3. The site inspection is a walking inspection of the entire site including the perimeter and sufficient transects to be able to inspect the entire surface and all features specifically described in this checklist.

4. A standard set of color $35 \mathrm{~mm}$ photographs is required. In addition, all anomalous features or new features (such as changes in adjacent area land use) are to be photographed. A photo log entry will be made for each photograph taken.

5. This unit will be inspected biannually with formal reporting to the Nevada Division of Environmental Protection to be done annually. The annual report will include an executive summary, this inspection checklist with field notes and photo log attached, and recommendations and conclusions.

\begin{tabular}{|c|c|c|c|}
\hline B. PREPARATION (To be completed prior to site visit) & YES & NO & EXPLANATION \\
\hline 1. Site as-built plans and site base map reviewed. & & & \\
\hline \\
\hline $\begin{array}{l}\text { a. Were anomalies or trends detected on previous } \\
\text { inspections? }\end{array}$ & & & \\
\hline b. Was maintenance performed? & & & \\
\hline \multirow{3}{*}{$\begin{array}{l}\text { 3. Site maintenance and repair records reviewed. } \\
\text { a. Has site repair resulted in a change from as-built } \\
\text { conditions? } \\
\text { b. Are revised as-builts available that reflect repair changes? }\end{array}$} & & & NA nopreviourecords \\
\hline & & & $N A$ \\
\hline & & & $N A$ \\
\hline C. SITE INSPECTION (To be completed during inspection) & YES & NO & EXPLANATION \\
\hline
\end{tabular}

1. Adjacent off-site features within watershed areas.

a. Have there been any changes in use of adjacent area?

b. Are there any new roads or trails?

c. Has there been a change in the position of nearby washes?

d. Has there been lateral excursion or erosion/deposition of nearby washes?

e. Are there new drainage channels?

f. Change in surrounding vegetation?

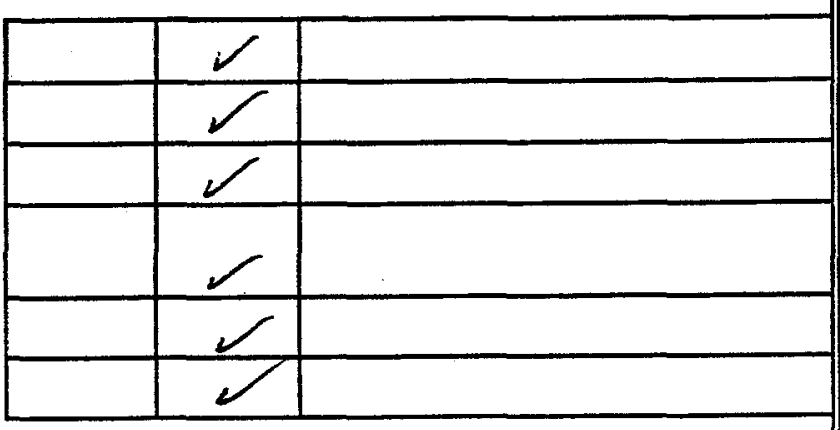

2. Security fence, signs.

a. Displacement of fences, site markers, boundary markers, or monuments?

b. Have any signs been damaged or removed? (Number of signs replaced:

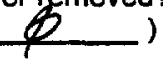

c. Were gates locked?

\begin{tabular}{|l|l|l|}
\hline & \multicolumn{1}{|l|}{} \\
\hline$V$ & $\begin{array}{l}\text { Two signs reattached to } \\
\text { fence }\end{array}$ \\
\hline & no loch present \\
\hline
\end{tabular}


CAU 404: ROLLER COASTER LAGOONS \& N. DISPOSAL TRENCH, POST-CLOSURE MONITORING CHECKLIST

3. Waste Unit cover.

a. Is there evidence of settling?

b. Is there cracking?

c. Is there evidence of erosion around the cap (wind or water)?

d. Is there evidence of animal burrowing?

e. Have the site markers been disturbed by man or natural processes?

f. Do natural processes threaten to integrity of any cover or site marker?

g. Other?

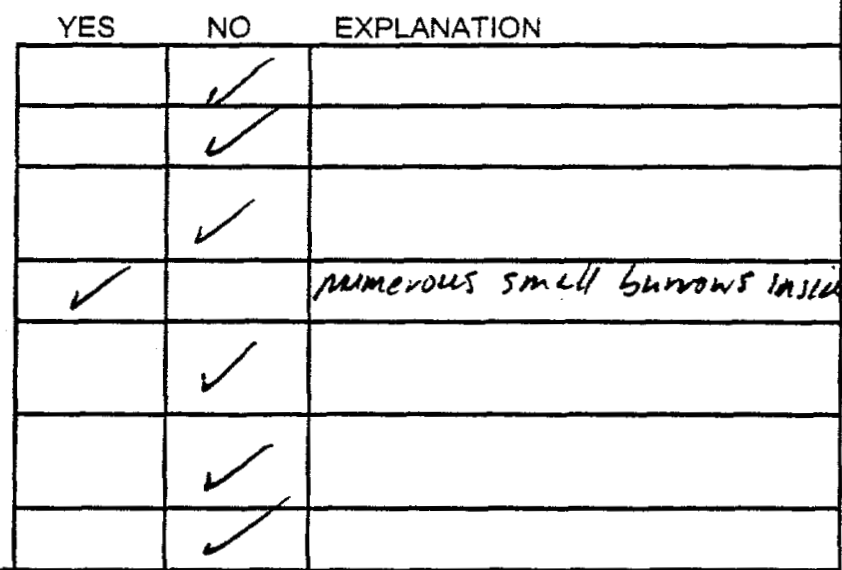

4. Vegetative cover

a. Is perimeter fence or mesh fencing damaged?

b. Is there evidence of horses or rabbits on site?

c. Is organic mulch adequate to prevent erosion?

d. Are weedy annual plants present? If yes, are they a problem?

e. Are seeded plant species found on site?

f. Is there evidence of plant mortality?

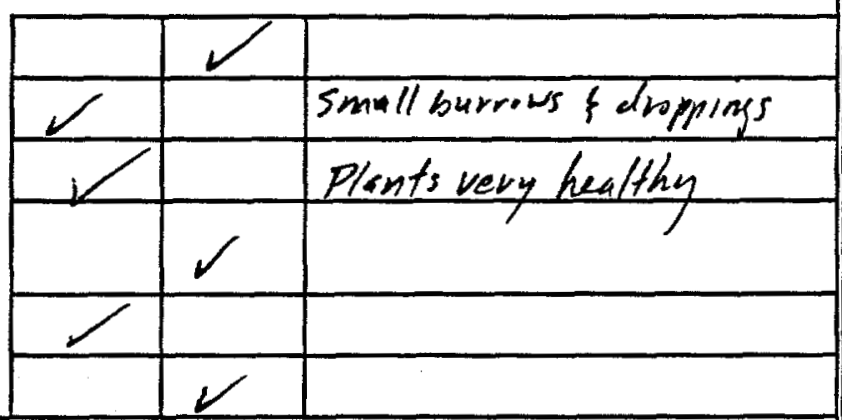

5. Photo Documentation

a. Has a photo log been prepared?

c. Number of photos exposed ( $Q$ )

\section{FIELD CONCLUSIONS}

1. Is there an imminent hazard to the integrity of the unit? (Immediate report required)

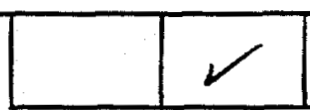

Person/Agency to whom report made:

2. Are more frequent inspections required?

3. Are existing maintenance/repair actions satisfactory?

4. Is other maintenance/repair necessary?

5. Is current status/condition of vegetative cover satisfactory?

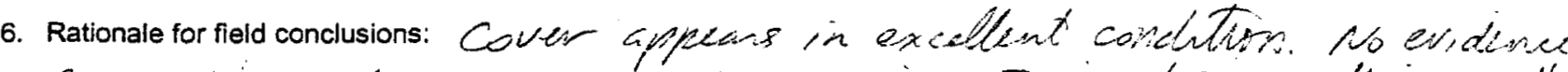

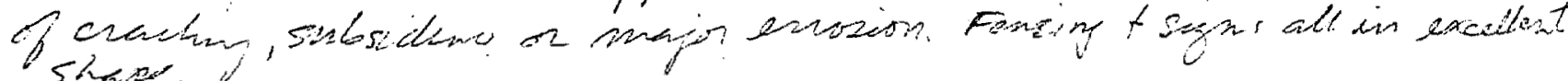

\section{E. CERTIFICATION}

I have conducted an inspection of the Roller Coaster Sewage Lagoons \& North Disposal Trench, CAU 404, at the TTR in accordance with the Post-Closure Monitoring Plan (see Closure Report) as recorded on this checklist, attached sheets, field notes, photo logs, and photographs.

Chief Inspector's Signature: $\mathbb{Z}-B$

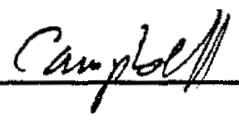

Printed Name:

\begin{tabular}{|l|l|l||}
\hline & \multicolumn{1}{|l|}{} \\
\hline & & \\
\hline & $\checkmark$ & \\
\hline & & \\
\hline
\end{tabular}


Post-Closure inspection Report

CAL No. 704

Roller Coaster Lagoons \& Trench

Revision: 0

Date: January 23, 2002

\section{ATTACHMENT B}

\section{FIELD NOTES}


16 TITLE

Work continued from Page $\mathrm{N} / \mathrm{A}$

$$
\sim 1430 \text { - Doublet } X_{1}
$$

- Walk the fere line to visually inspect the site. The fenced aced was well cover nd with vejstetion 5 ard was in sold condition. Numerous extract \& half bumbles were prefect adjacent to the fere or the exterior of the site. Scend bomblets were also present within the fenced area.

$10 \sim 1500$ - Roller Coaster Beware Lasoows

- Walled the exterior fence lire of site. The site was in sod corditier and well covered with vegetation. Two posted ferne sises were down. A lave burrow was present or the east side of 15 the cap margin and a large ariel appeared to be present is the burrow at the tire of inspection. Two pieces of red-clay pipe were present or the south east marry of the fenced aver wen the base of the cap slope. The pipe append to extend

20 undergrad. No potable signs of erosion war observed.

$\sim 1545$ - Cactus Springy Waste Trenches.

- Walked the exterior fere line to vizulle in spent the site.

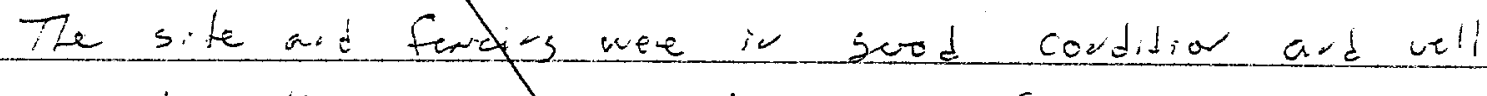

25 covert with vesetertor. No signs of evasive were observes. The criterion of the cast marker of the site stringed a lame guatiaty of tumble mads.

SCIENTIFIC BINDERY PRODUCTONS CHICAGO GOBOS MadE In USA

Work continued to Page 17

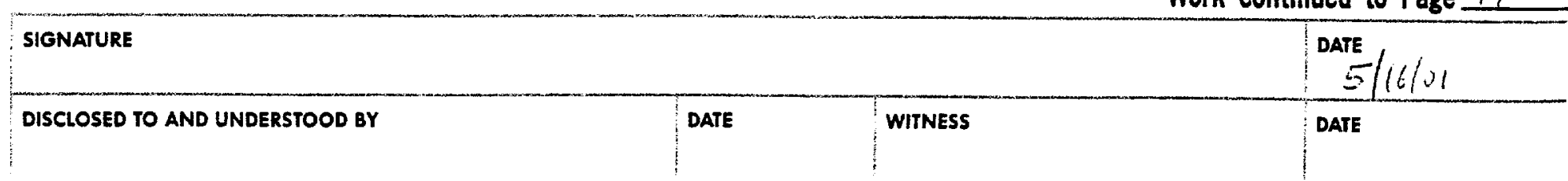


22 TITLE

Work continued from Page 21
PROJECT NO.

BOOK NO.

Roller Coaster Sewage Lo yon (CAu404)

1223 Amie on sita.

bates, fence, signs all in excellent condition.

Cover vegetation healthy and more dense than outside force.

5 Small burrow's present at base of fence line, bach filled by band. Numerous small hamal burrows present inside feme bury fencing is not burned as at other sites allowing animals access under fencing No burrows present on top of raised ar la.

No evidence of erosion of cover side slope

10

Draining swill north of cover in excellent contrition - no exponent erosion Reattached two signs with bog rings

1300 Depart site

1310 Rollercoaster Rad Sate site (canyon)

15 Barbed wire fencing in good condition. No bung fencing pt present. Postings "Underground Rachoactive Maternal" still up/ tin place Vegetation infill fence ven healthy.

Numerous small mamas burrows present inside fenced area and on side slopes of cover.

20 No the to integrity of cover

All signs in good shape

1326 Depart site

1335 - AB- 4 site (CAM 423)

25

All 5 abore-grade monuments in good condition

All attached sinus in good condition

Vegetation mainly helogeten some native species all head thy but sparse.

Many small mama burrows present.

SCIENTFIC BINDERY PRODUCTiONS CHICAGO solos Made in UsA

Work continued to Page 23

SIGNATURE

DISCLOSED TO AND UNDERSTOOD BY

DATE

WITNESS

DATE $/ / 6 / 01$

ot 171\%

DATE

- 
Post-Closure Inspection Report

CAU No. 404

Roller Coaster Lagoons \& Trench

Revision: 0

Date: January 23, 2002

\section{ATTACHMENT C}

\section{PHOTOGRAPH LOG AND PHOTOGRAPHS}




\section{PHOTOGRAPH LOG}

\begin{tabular}{|c|c|l||}
\hline $\begin{array}{c}\text { PHOTO } \\
\text { NUMBER }\end{array}$ & DATE & \multicolumn{1}{c|}{ DESCRIPTION } \\
\hline \hline 1 & $05 / 16 / 2001$ & View to the east along southern fence line. \\
\hline 2 & $05 / 16 / 2001$ & View of cover looking northwest from southeast fence corner. \\
\hline 3 & $05 / 16 / 2001$ & View to the northeast along northern fence line. \\
\hline 4 & $05 / 16 / 2001$ & $\begin{array}{l}\text { View of the east of cover from inside fence line. Note the } \\
\text { presence of sparse healthy native grass and brush species. }\end{array}$ \\
\hline 5 & $11 / 06 / 2001$ & View looking east from outside fence at site. \\
\hline 6 & $11 / 06 / 2001$ & $\begin{array}{l}\text { View looking east at cover from inside fence. Note the presence } \\
\text { of sparse healthy native grass and shrub species on and about } \\
\text { cover. }\end{array}$ \\
\hline 7 & $11 / 06 / 2001$ & Small mammal burrow holes inside fence line. \\
\hline 8 & $11 / 06 / 2001$ & View to southwest of cover and associated revegetated area. \\
\hline \hline
\end{tabular}


Post-Closure Inspection Report

CAU No. 404

Revision: 0

Date: January 23, 2002
Roller Coaster Lagoons \& Trench

$\%$

$\$$

$\infty$

2

-

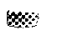

THIS PAGE INTENTIONALLY LEFT BLANK

.

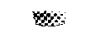

\%

w:

Ses

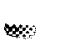

(1) 


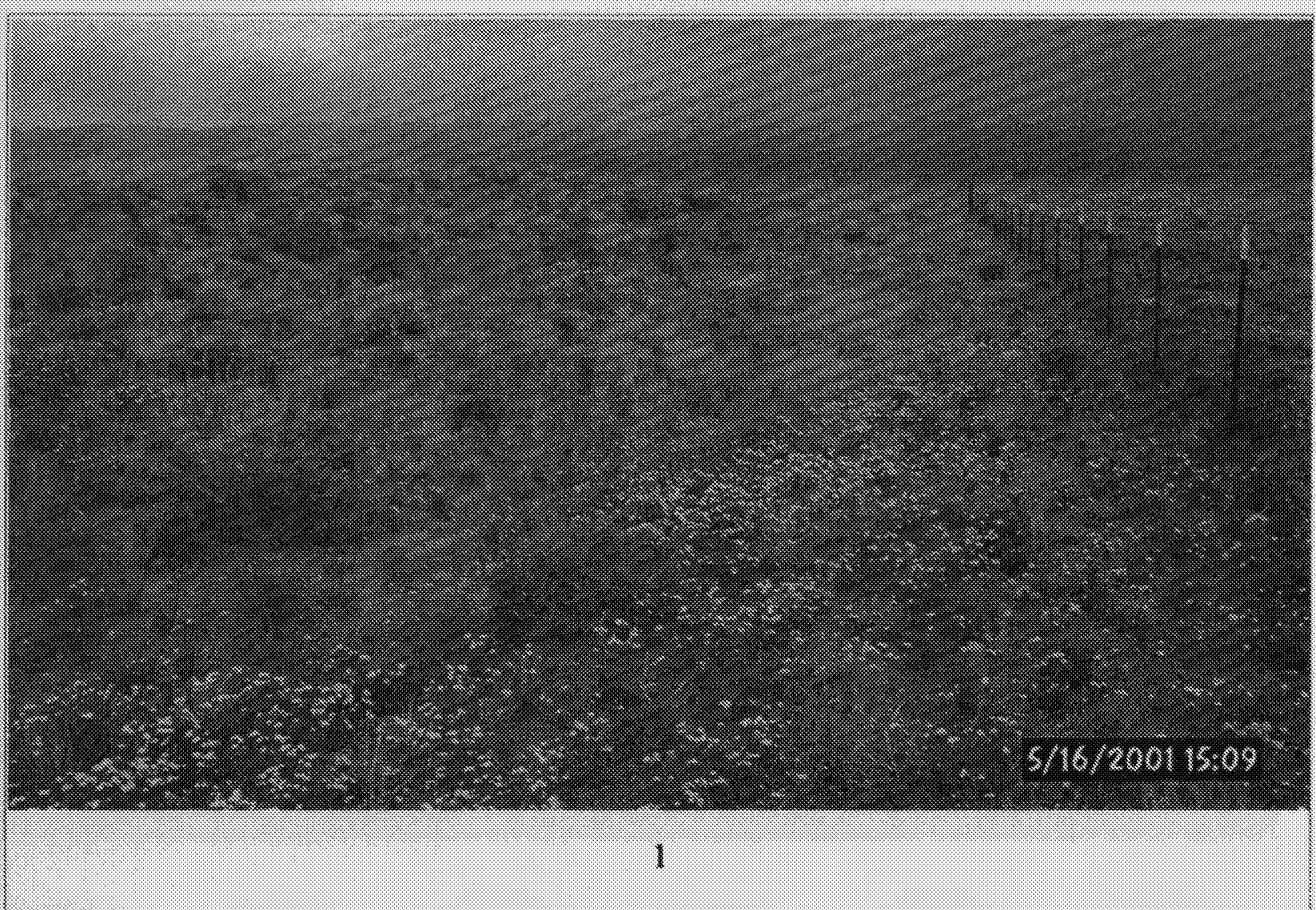

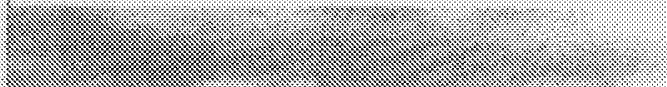
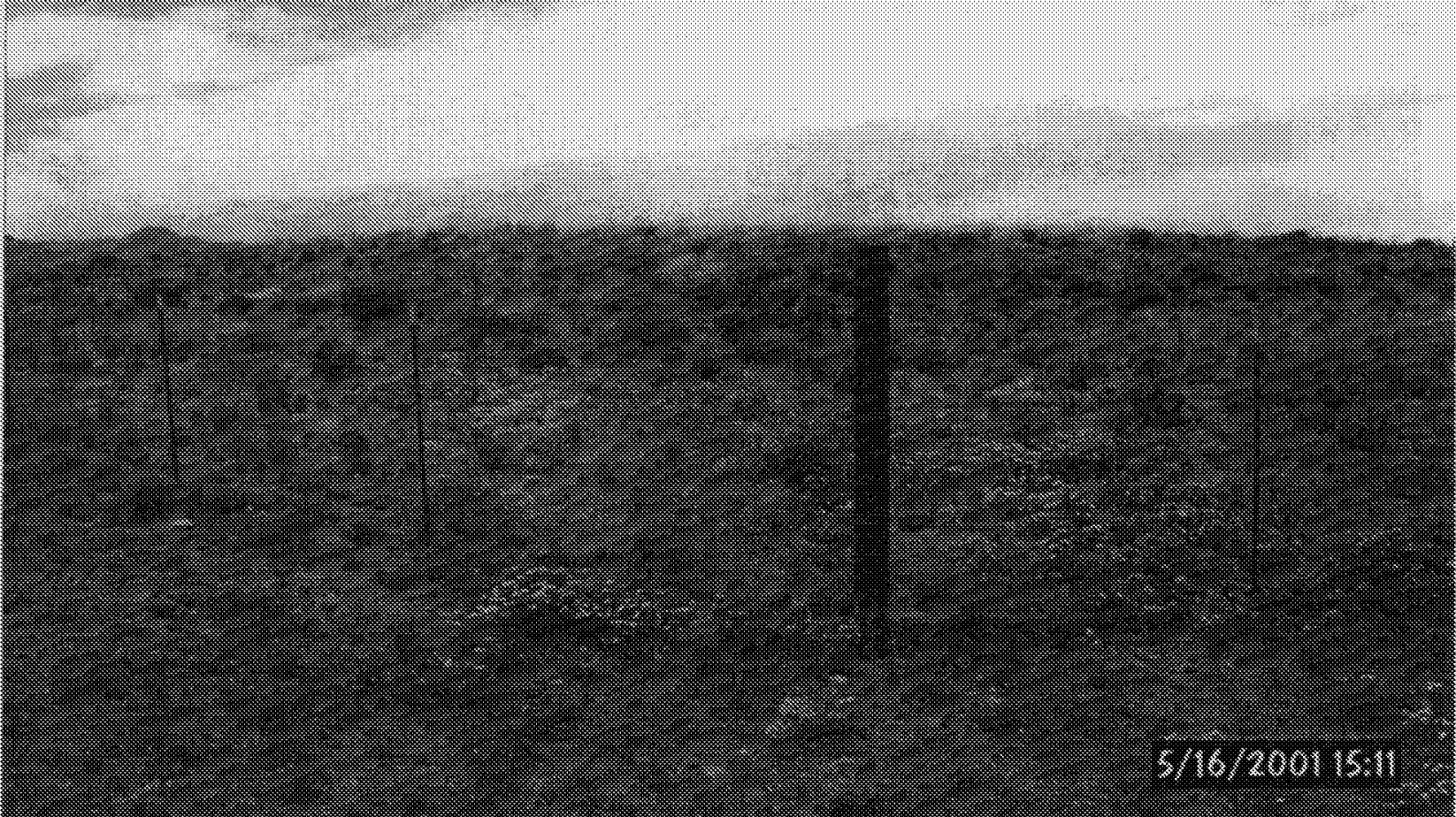


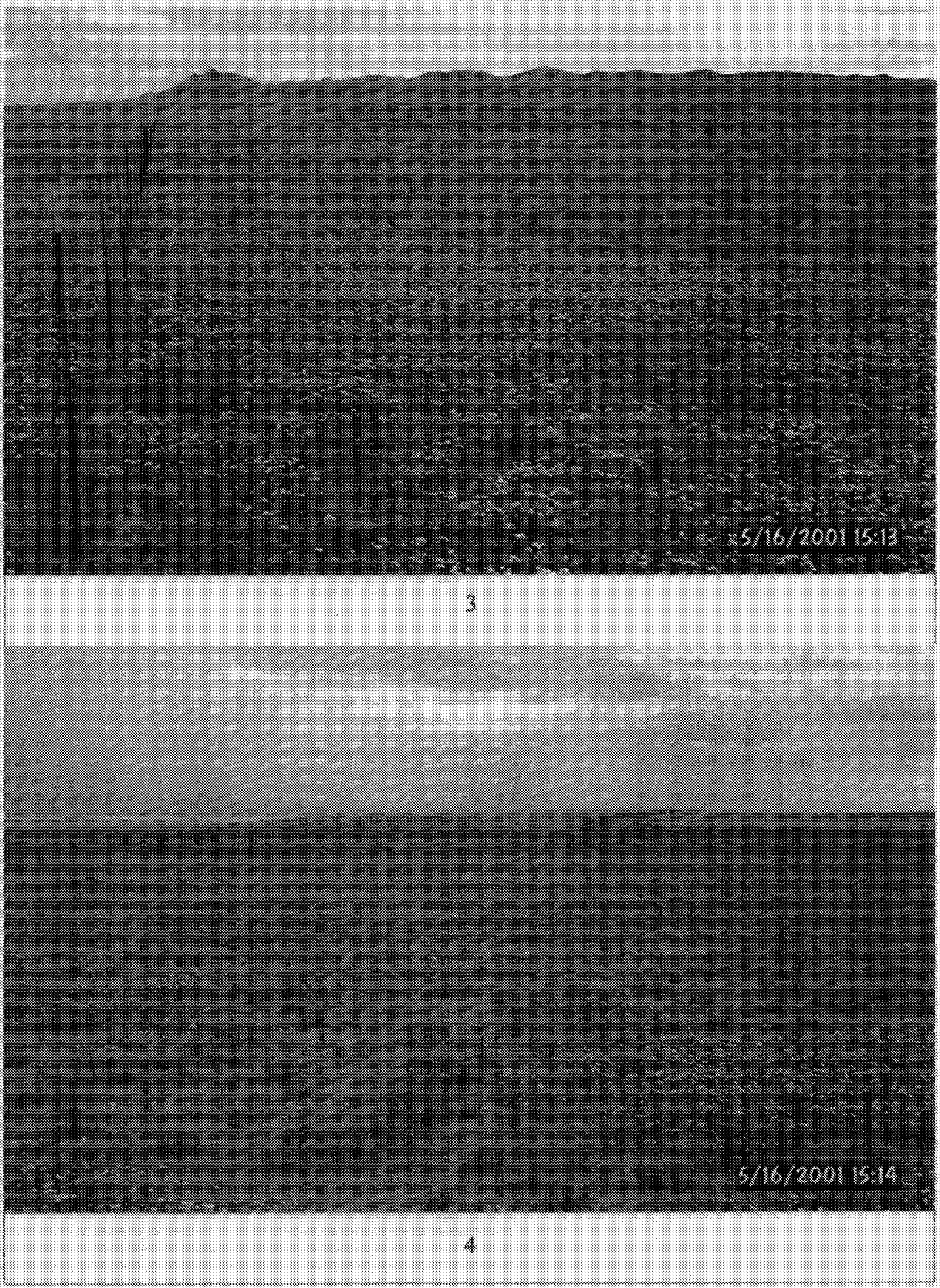




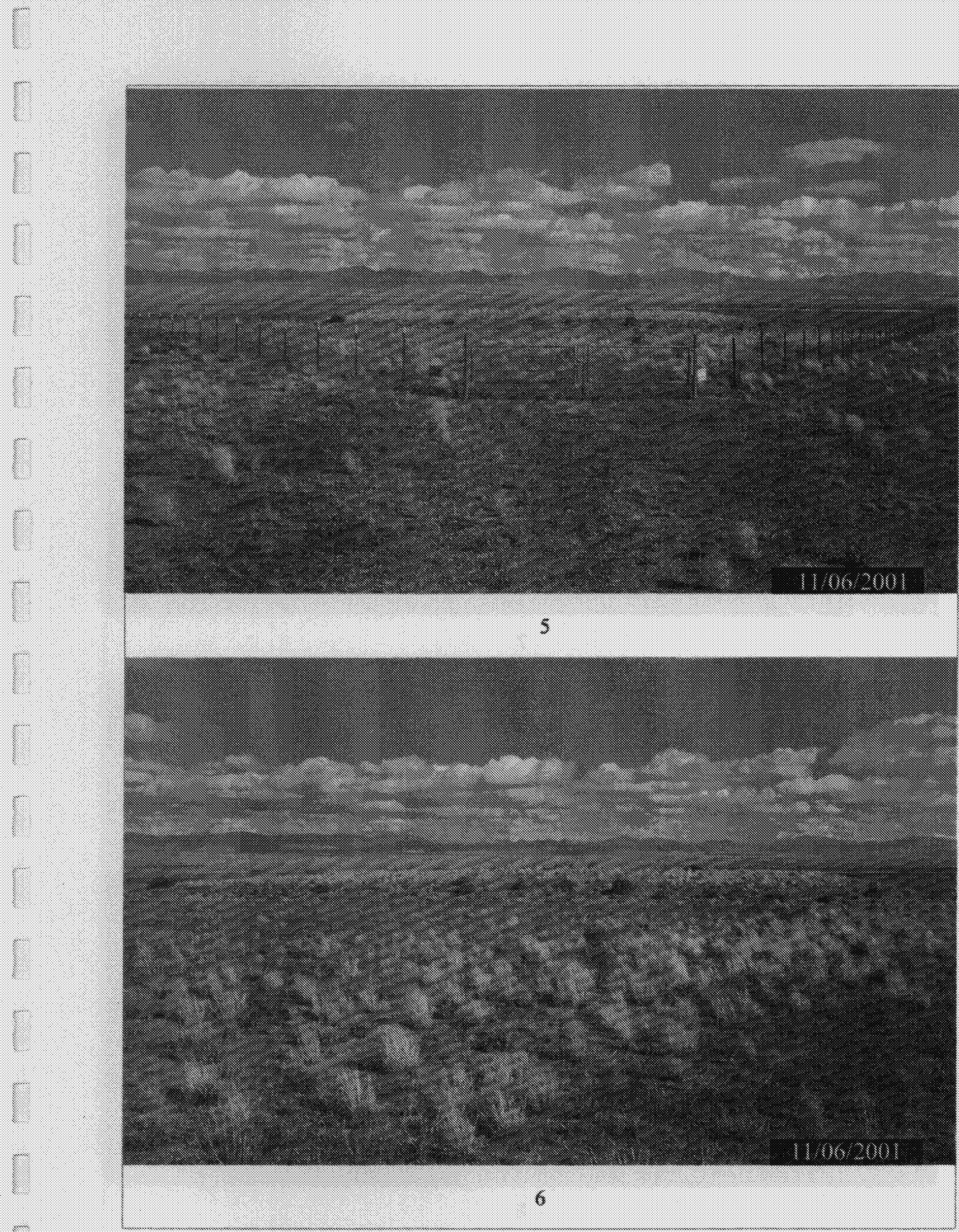




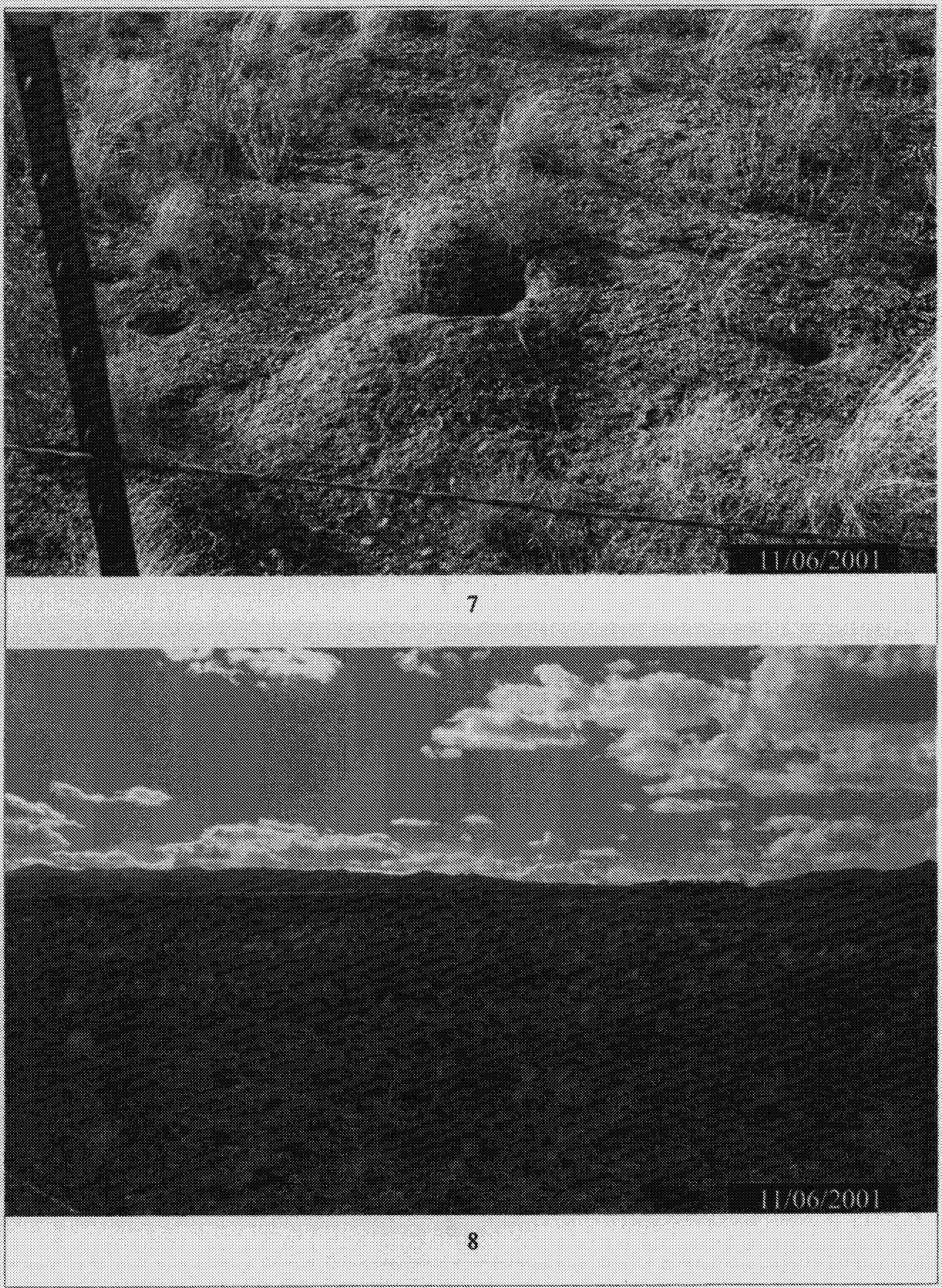


Post-Closure Inspection Repont

CAU No. 404

Roller Coaster Lagoons \& Trench

Revision: 0

Date: January 23, 2002

\section{THIS PAGE INTENTIONALLY LEFT BLANK}




\section{DISTRIBUTION LIST}

*Provide copy of initial distribution of Revision 0; remainder of list gets Revision 0 if approved without changes. The entire list receives Revision 1, if issued.

\section{Nevada Department of Environmental Protection}

Paul Liebendorfer

Bureau of Federal Facilities

Division of Environmental Protection

333 W. Nye Lane, Room 138

Carson City, NV 89706-0866

Supervisor, Las Vegas Office

Bureau of Federal Facilities

Division of Environmental Protection

555 E. Washington, Suite 4300

Las Vegas, NV 89010-1043

\section{U.S. Department of Energy}

Janet Appenzeller-Wing

Project Manager

Environmental Restoration Division

U.S. Department of Energy

National Nuclear Security Administration

Nevada Operations Office

P.O. Box $98518 \mathrm{M} / \mathrm{S} 505$

Las Vegas, NV 89193-8518

Kevin Cabble

Environmental Restoration Division

U.S. Department of Energy

National Nuclear Security Administration

Nevada Operations Office

P.O. Box $98518 \mathrm{M} / \mathrm{S} 505$

Las Vegas, NV 89193-8518
2 (Controlled)*

1 (Controlled)* 


\section{DISTRIBUTION LIST (Continued)}

\section{U.S. Department of Energy (continued)}

Sabrina Lawrence

1 (Controlled)*

Environmental Restoration Division

U.S. Department of Energy

National Nuclear Security Administration

Nevada Operations Office

P.O. Box $98518 \mathrm{M} / \mathrm{S} 505$

Las Vegas, NV 89193-8518

U.S. Department of Energy

1 (electronic copy)

Office of Scientific and Technical Information

P.O. Box 62

Oak Ridge, TN 37831-0062

U.S. Department of Energy

1 (Controlled) \&

National Nuclear Security Administration

1 (Uncontrolled)

Nevada Operations Office

Public Reading Facility

P.O. Box $98521 \mathrm{M} / \mathrm{S}$ NLV040

Las Vegas, NV 89193-8521

U.S. Department of Energy

1 (Uncontrolled)

National Nuclear Security Administration

Nevada Operations Office

Technical Information Resource Center

P.O. Box $98521 \mathrm{M} / \mathrm{S} 505$

Las Vegas, NV 89193-8521

\section{Bechtel Nevada}

Correspondence Control

1 (Uncontrolled)*

Bechtel Nevada

P.O. Box $98521 \mathrm{M} / \mathrm{S}$ NLV008

Las Vegas, NV 89193-8521 


\section{DISTRIBUTION LIST (Continued)}

\section{Bechtel Nevada (continued)}

Environmental Management Library

1 (Uncontrolled)*

Bechtel Nevada

P.O. Box 98521 N/S NLV080

Las Vegas, NV 89193-8521

Kevin Campbell

1 (Uncontrolled)*

Bechtel Nevada

P.O. Box $98521 \mathrm{M} / \mathrm{S}$ NTS306

Las Vegas, NV 89193-8521

Ann Heidema

1 (Uncontrolled)

Bechtel Nevada

P.O. Box $98521 \mathrm{M} / \mathrm{S}$ NLV022

Las Vegas, NV 89193-8521

Ronald Jackson

1 (Uncontrolled)*

Bechtel Nevada

P.O. Box $98521 \mathrm{M} / \mathrm{S}$ NTS306

Las Vegas, NV 89193-8521

Wayne Johnson

1 (Uncontrolled)*

Bechtel Nevada

P.O. Box $98521 \mathrm{M} / \mathrm{S}$ NTS306

Las Vegas, NV 89193-8521

Steve Nacht

1 (Uncontrolled)*

Bechtel Nevada

P.O. Box $98521 \mathrm{M} / \mathrm{S}$ NTS306

Las Vegas, NV 89193-8521

\section{IT Corporation}

Lynn Kidman

1 (Uncontrolled)*

IT Corporation

P.O. Box $93838 \mathrm{M} / \mathrm{S} 439$

Las Vegas, NV 89193-8521 


\section{DISTRIBUTION LIST (Continued)}

\section{IT Corporation (continued)}

Garry Romano

1 (Controlled)

IT FFACO Support Office

IT Corporation

P.O. Box $93838 \mathrm{M} / \mathrm{S} 439$

Las Vegas, NV 89193-8521

\section{State Of Nevada}

Manager, Northern Nevada

FFACO Public Reading Facility

1 (Controlled) \&

Nevada State Library and Archives Federal Publications

100 North Stewart Street

Carson City, NV 89701-4285 